\title{
A new T-circuit model of wind turbine generator for power system steady state studies
}

\author{
Rudy Gianto, Kho Hie Khwee \\ Department of Electrical Engineering, Tanjungpura University, Indonesia
}

\begin{tabular}{l} 
Article Info \\
\hline Article history: \\
Received Sep 16, 2020 \\
Revised Nov 13, 2020 \\
Accepted Dec 5, 2020 \\
\hline
\end{tabular}

\section{Keywords:}

Induction generator

Load flow

Power system

Steady state model

Wind turbine

\begin{abstract}
Modeling of wind power plant (WPP) is a crucial issue in power system studies. In this paper, a new model of WPP for steady state (i.e. load flow) studies is proposed. Similar to the previous T-circuit based models, it is also developed based on equivalent T-circuit of the WPP induction generator. However, unlike in the previous models, the mathematical formulation of the new model is shorter and less complicated. Moreover, the derivation of the model in the present work is also much simpler. Only minimal mathematical operations are required in the process. Furthermore, the rotor voltage value of the WPP induction generator is readily available as an output of the proposed new model. This rotor voltage value can be used as a basis to calculate the induction generator slip. Validity of the new method is tested on a representative 9-bus electrical power system installed with WPP. Comparative studies between the proposed method (new model) and other method (previous model) are also presented.
\end{abstract}

This is an open access article under the $\underline{C C B Y-S A}$ license.

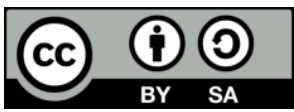

Corresponding Author:

Rudi Gianto

Department of Electrical Engineering

Tanjungpura University

Jalan Prof. Dr. H. Hadari Nawawi, Pontianak 78124, Indonesia

Email: rudy.gianto@ee.untan.ac.id

\section{INTRODUCTION}

Modeling of WPP is a crucial issue in steady state and dynamic analyses of modern electric power system. Several interesting models have been investigated to enable incorporating the WPP into the studies. In the context of power system steady state (i.e. load flow) studies, some recent methods in the modeling can be found in [1-23]. The present paper investigates a new method for modeling WPP to be incorporated into modern power system load flow analysis.

Steady state model of WPP is developed where equivalent T-circuit of the WPP induction generator has been used as a basis in the model derivation [2, 16-18, 22, 23]. For each WPP, the developed model formulation consists of two nonlinear equations. Also, the unknown quantities (i.e. quantities to be determined or calculated) in the formulation are only the WPP active- and reactive-power output. However, in the method proposed in $[2,16-18,22,23]$, the WPP has been represented with relatively long and complex mathematical expressions.

In the present paper, a new model of WPP is proposed. Similar to the models discussed in [2, 16-18, $22,23]$, it is also developed based on equivalent T-circuit of the WPP induction generator. However, the derivation process of the new model is much simpler than that proposed in $[2,16,17,18,22,23]$. Only minimal mathematical operations are required in the process. As a result, simpler WPP steady state model can be obtained. Moreover, the rotor voltage value of the WPP induction generator is readily available as an output of the proposed model. This rotor voltage value can be used as a basis to calculate the induction 
generator slip. The validity of the proposed method is then tested on a representative 9-bus electrical power system installed with WPP.

To be systematic, the rest of the paper is arranged as follows: Section 2 gives the load flow problem formulation of a general power system without WPP. Section 3 addresses the proposed method of WPP modeling. Incorporation of the model into load flow analysis is also discussed in this section. Validity of the proposed method is investigated in section 4. Effects of shunt capacitor installation on WPP steady state performances (voltage profile, power output and slip) are also presented in this section. Finally, some important conclusions of the present work are given in section 5.

\section{FORMULATION OF LOAD FLOW PROBLEM}

The formulation of power flow problems can be obtained through equations that describe the performance of power system network in the forms of admittance. These equations are then combined with the formulations of bus power injection to obtain [24].

$$
S_{\mathrm{Gi}}-S_{\mathrm{Li}}-\mathrm{V}_{\mathrm{i}} \sum_{j=1}^{\mathrm{n}} Y_{\mathrm{ij}}^{*} \mathrm{~V}_{\mathrm{j}}^{*}=0
$$

where:

$$
\begin{array}{lll}
\mathrm{i}=1,2, \ldots, \mathrm{n} & : & \text { bus number } \\
\mathrm{n} & : & \text { total number of buses } \\
\mathrm{S}_{\mathrm{Gi}}=\mathrm{P}_{\mathrm{Gi}}+\mathrm{jQ}_{\mathrm{Gi}} & : & \text { power generation at bus } \mathrm{i} \\
\mathrm{S}_{\mathrm{Li}}=\mathrm{P}_{\mathrm{Li}}+\mathrm{j} \mathrm{Q}_{\mathrm{Li}} & : & \text { power load at bus } \mathrm{i} \\
\mathrm{V}_{\mathrm{i}}=\left|\mathrm{V}_{\mathrm{i}}\right| \mathrm{e}^{\mathrm{j} \delta \mathrm{i}} & : & \text { voltage at bus } \mathrm{i} \\
\mathrm{Y}_{\mathrm{ij}}=\left|\mathrm{Y}_{\mathrm{ij}}\right| \mathrm{e}^{\mathrm{j} \theta \mathrm{ij}} & : & \text { ij-th element of admittance matrix }
\end{array}
$$

To be able to find a valid solution to (1), in the power flow analysis, the following three types ofsystem buses are usually defined: reference (slack), generator (PV) and load (PQ) buses as shown in Table 1. This definition is intended to make the number variables equal to the number of equations so that a correct and valid solution to (1) is obtainable.

Table 1. Bus types and variables

\begin{tabular}{cccc}
\hline No & Bus Type & Known Variable & Unknown Variable \\
\hline 1 & Slack & $|\mathrm{Y}|, \mathrm{q}, \mathrm{P}_{\mathrm{L}}, \mathrm{Q}_{\mathrm{L}},|\mathrm{V}|$ and $\mathrm{d}=0$ & $\mathrm{P}_{\mathrm{G}}$ and $\mathrm{Q}_{\mathrm{G}}$ \\
2 & $\mathrm{PQ}$ & $|\mathrm{Y}|, \mathrm{q}, \mathrm{P}_{\mathrm{L}}, \mathrm{Q}_{\mathrm{L}}$, and $\mathrm{P}_{\mathrm{G}}=\mathrm{Q}_{\mathrm{G}}=0$ & $|\mathrm{~V}|$ and $\mathrm{d}$ \\
3 & $\mathrm{PV}$ & $|\mathrm{Y}|, \mathrm{q}, \mathrm{P}_{\mathrm{L}}, \mathrm{Q}_{\mathrm{L}}, \mathrm{P}_{\mathrm{G}}$ and $|\mathrm{V}|$ & $\mathrm{Q}_{\mathrm{G}}$ and $\mathrm{d}$ \\
\hline
\end{tabular}

\section{PROPOSED MODEL OF WPP}

In Figure 1(a), a WPP connected to bus $\mathrm{k}$ of an electric power system is shown. The main energy converter of the WPP is SCIG (squirrel cage induction generator). Separately, the SCIG is shown in Figure 1(b). Mechanical power input to the SCIG is $\mathrm{P}_{\mathrm{m}}$, and the SCIG (i.e. WPP) electrical power output is $\mathrm{S}_{\mathrm{g}}=\mathrm{P}_{\mathrm{g}}+\mathrm{j} \mathrm{Q}_{\mathrm{g}}$. Figures 2 and 3 show the steady state equivalent circuits of SCIG. In Figure $3, \mathrm{Z}_{\mathrm{S}}, \mathrm{Z}_{\mathrm{R}}$ and $\mathrm{Z}_{\mathrm{M}}$ represent the impedances of stator, rotor and magnetic core circuits, respectively. These impedances are given by:

$$
\begin{aligned}
& \mathrm{Z}_{\mathrm{S}}=\mathrm{R}_{\mathrm{S}}+\mathrm{j} \mathrm{X}_{\mathrm{S}} \\
& \mathrm{Z}_{\mathrm{R}}=\mathrm{R}_{\mathrm{R}}+\mathrm{j} \mathrm{X}_{\mathrm{R}} \\
& \mathrm{Z}_{\mathrm{M}}=\mathrm{j} \mathrm{R}_{\mathrm{c}} \mathrm{X}_{\mathrm{m}} /\left(\mathrm{R}_{\mathrm{c}}+\mathrm{j} \mathrm{X}_{\mathrm{m}}\right)
\end{aligned}
$$

It is also to be noted that in Figure 2, $\mathrm{s}$ is the machine (i.e. SCIG) slip, and $\mathrm{R}_{2}(1-\mathrm{s}) / \mathrm{s}$ is a variable resistance where the turbin mechanical power $\mathrm{P}_{\mathrm{m}}$ is assumed to be dissipated into. Based on Figures 2 and 3 , the dissipated power can be computed using: 
$\mathrm{P}_{\mathrm{m}}=-\mathrm{R}_{\mathrm{R}} \frac{1-\mathrm{s}}{\mathrm{s}} \mathrm{I}_{\mathrm{R}} \mathrm{I}_{\mathrm{R}}^{*}$

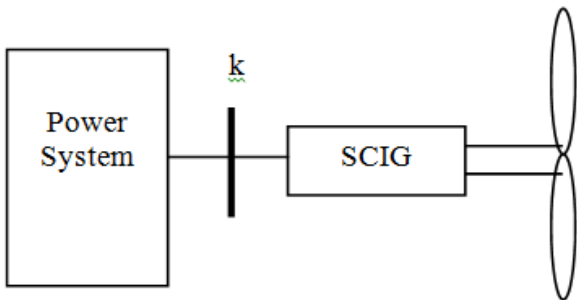

(a)

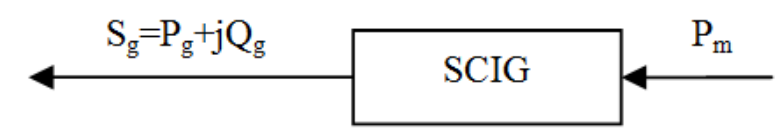

(b)

Figure 1. Wind power plant connected to power system

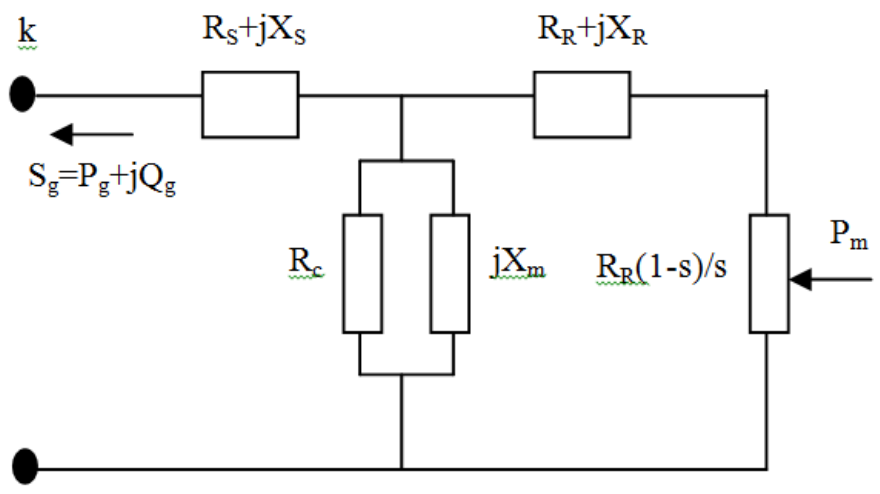

Figure 2. Steady state equivalent circuit of SCIG

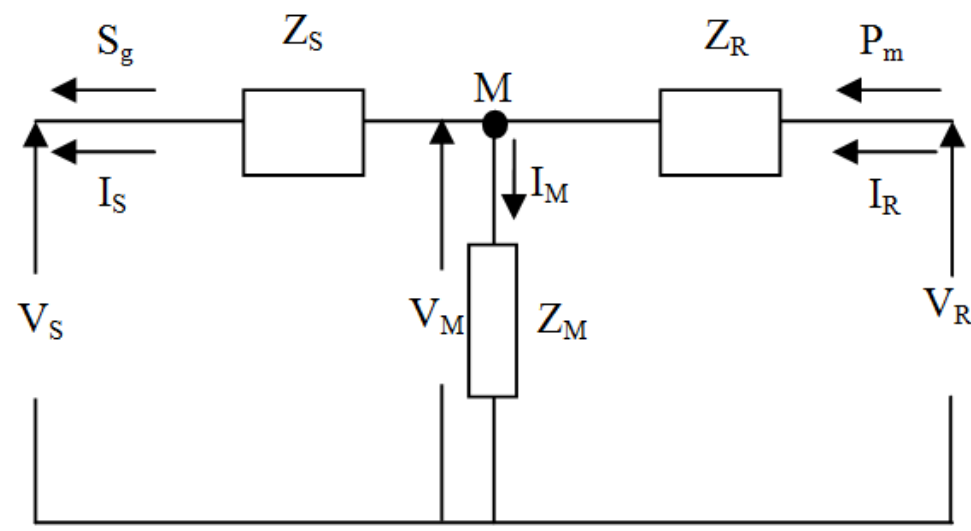

Figure 3. Steady state equivalent circuit of SCIG in terms of impedances

Also, by looking at Figure 3, the formulas for WPP electrical power output $\left(\mathrm{S}_{\mathrm{g}}\right)$ and turbine mechanical power input $\left(\mathrm{S}_{\mathrm{m}}\right)$ can be written as:

$$
\begin{aligned}
& S_{g}=P_{g}+j Q_{g}=V_{S} I_{S}^{*} \\
& S_{m}=P_{m}+j 0=V_{R} I_{R}^{*}
\end{aligned}
$$


Based on (4) and (5), the stator current $\left(\mathrm{I}_{\mathrm{S}}\right)$ as a function of electric power output $\left(\mathrm{S}_{\mathrm{g}}\right)$ and stator voltage $\left(V_{S}\right)$, and the rotor current $\left(\mathrm{I}_{\mathrm{R}}\right)$ as a function of mechanical power input $\left(\mathrm{P}_{\mathrm{m}}\right)$ and rotor voltage $\left(\mathrm{V}_{\mathrm{R}}\right)$ are formulated as:

$$
\begin{gathered}
I_{S}=\frac{S_{g}^{*}}{V_{S}^{*}} \\
I_{R}=\frac{P_{m}}{V_{R}^{*}}
\end{gathered}
$$

Furthermore, by applying basic electric circuit theories (i.e. Kirchhoff's and Ohm's laws) to circuit in Figure 3, the following equations can also be obtained (derivation is given in the appendix):

$$
\begin{aligned}
& \mathrm{V}_{S}-\mathrm{V}_{\mathrm{R}}+\mathrm{Z}_{\mathrm{S}} \mathrm{I}_{\mathrm{S}}+\mathrm{Z}_{\mathrm{R}} \mathrm{I}_{\mathrm{R}}=0 \\
& \mathrm{~V}_{\mathrm{S}}+\left(\mathrm{Z}_{\mathrm{S}}+\mathrm{Z}_{\mathrm{M}}\right) \mathrm{I}_{\mathrm{S}}-\mathrm{Z}_{\mathrm{M}} \mathrm{I}_{\mathrm{R}}=0
\end{aligned}
$$

Substituting (6) and (7) into (8)and (9) will result in:

$$
\begin{aligned}
& \mathrm{V}_{\mathrm{S}}-\mathrm{V}_{\mathrm{R}}+\mathrm{Z}_{\mathrm{S}} \frac{\mathrm{S}_{\mathrm{g}}^{*}}{\mathrm{~V}_{\mathrm{S}}^{*}}+\mathrm{Z}_{\mathrm{R}} \frac{\mathrm{P}_{\mathrm{m}}}{\mathrm{V}_{\mathrm{R}}^{*}}=0 \\
& \mathrm{~V}_{\mathrm{S}}+\left(\mathrm{Z}_{\mathrm{S}}+\mathrm{Z}_{\mathrm{M}}\right) \frac{\mathrm{S}_{\mathrm{g}}^{*}}{\mathrm{~V}_{\mathrm{S}}^{*}}-\mathrm{Z}_{\mathrm{M}} \frac{\mathrm{P}_{\mathrm{m}}}{\mathrm{V}_{\mathrm{R}}^{*}}=0
\end{aligned}
$$

In (10) and (11), are the proposed steady state model of WPP. It is to be noted that, in (10) and (11), $\mathrm{V}_{\mathrm{S}}$ is the stator voltage which is also the voltage at WPP terminal (i.e. $\mathrm{V}=|\mathrm{V}| \mathrm{e}^{\mathrm{j} \delta}$ ), and $\mathrm{V}_{\mathrm{R}}=|\mathrm{V}| \mathrm{e}^{\mathrm{j} \alpha}$ is the rotor voltage. Moreover, the active and reactive power generations $\left(\mathrm{P}_{\mathrm{G}}\right.$ and $\left.\mathrm{Q}_{\mathrm{G}}\right)$ at WPP bus, are also the WPP active and reactive power outputs $\left(\mathrm{P}_{\mathrm{g}}\right.$ and $\left.\mathrm{Q}_{\mathrm{g}}\right)$, or: $\mathrm{P}_{\mathrm{G}}=\mathrm{P}_{\mathrm{g}}$ and $\mathrm{Q}_{\mathrm{G}}=\mathrm{Q}_{\mathrm{g}}$. All of the equations to be solved and quantities to be determined in the complete load flow formulation are presented in Table 2. It is also worth mentioning here that there is an alternative expression to (11). This alternative formulation can be found in the appendix.

Table 2. Bus types and variables for system with WPP

\begin{tabular}{ccccc}
\hline No & Equation(s) & Bus Type & Known Variable & Unknown Variable \\
\hline 1 & $(1)$ & Slack & $|\mathrm{Y}|, \theta, \mathrm{P}_{\mathrm{L}}, \mathrm{Q}_{\mathrm{L}},|\mathrm{V}|$ and $\delta=0$ & $\mathrm{P}_{\mathrm{G}}$ and $\mathrm{Q}_{\mathrm{G}}$ \\
2 & $(1)$ & $\mathrm{PQ}$ & $|\mathrm{Y}|, \theta, \mathrm{P}_{\mathrm{L}}, \mathrm{Q}_{\mathrm{L}}$, and $\mathrm{P}_{\mathrm{G}}=\mathrm{Q}_{\mathrm{G}}=0$ & $|\mathrm{~V}|$ and $\delta$ \\
3 & $(1)$ & $\mathrm{PV}$ & $|\mathrm{Y}|, \theta, \mathrm{P}_{\mathrm{L}}, \mathrm{Q}_{\mathrm{L}}, \mathrm{P}_{\mathrm{G}}$ and $|\mathrm{V}|$ & $\mathrm{Q}_{\mathrm{G}}$ and $\delta$ \\
4 & $(1),(10),(11)$ & WPP & $|\mathrm{Y}|, \theta, \mathrm{P}_{\mathrm{L}}$, and $\mathrm{Q}_{\mathrm{L}}$ & $\mathrm{P}_{\mathrm{G}}=\mathrm{P}_{\mathrm{g}}, \mathrm{Q}_{\mathrm{G}}=\mathrm{Q}_{\mathrm{g}},|\mathrm{V}|, \delta$, \\
& & & & $\left|\mathrm{V}_{\mathrm{R}}\right|$ and $\alpha$ \\
\hline
\end{tabular}

\section{RESULT AND DISCUSSION}

\subsection{Test system}

The new WPP model proposed in section 3 will be tested by using a power system shown in Figure 4. This power system is based on 9-bus system adopted from [25]. The test system is then modified by adding a WPP to bus 8 via a step-up transformer. Data for the test system (including the WPP) are shown in Tables 3-5 (all data are in pu on 100 MVA base). 


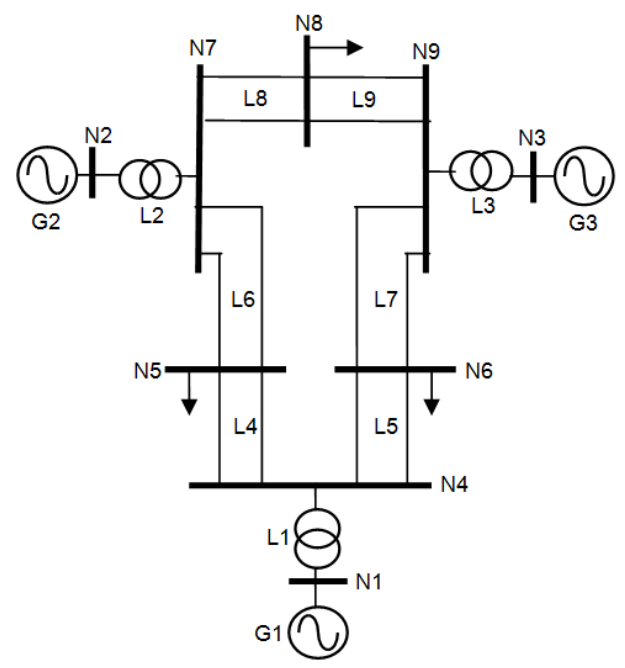

Figure 4. Test system

Table 3. Branch (line) data

\begin{tabular}{cccc}
\hline \multirow{2}{*}{ Line } & $\begin{array}{c}\text { Bus } \\
\mathrm{p}-\mathrm{q}\end{array}$ & $\begin{array}{c}\text { Series } \\
\text { Impedance }(\mathrm{Z})\end{array}$ & $\begin{array}{c}\text { Shunt Admittance } \\
(\mathrm{Ysh} / 2)\end{array}$ \\
\hline 1 & $1-4$ & $\mathrm{j} 0.1184$ & 0 \\
2 & $2-7$ & $\mathrm{j} 0.1823$ & 0 \\
3 & $3-9$ & $\mathrm{j} 0.2399$ & 0 \\
4 & $4-5$ & $0.0100+\mathrm{j} 0.0850$ & $\mathrm{j} 0.0880$ \\
5 & $4-6$ & $0.0170+\mathrm{j} 0.0920$ & $\mathrm{j} 0.0790$ \\
6 & $5-7$ & $0.0320+\mathrm{j} 0.1610$ & $\mathrm{j} 0.1530$ \\
7 & $6-9$ & $0.0390+\mathrm{j} 0.1700$ & $\mathrm{j} 0.1790$ \\
8 & $7-8$ & $0.0085+\mathrm{j} 0.0720$ & $\mathrm{j} 0.0745$ \\
9 & $8-9$ & $0.0119+\mathrm{j} 0.1008$ & $\mathrm{j} 0.1045$ \\
\hline
\end{tabular}

Table 4. Bus (node) data

\begin{tabular}{cccccc}
\hline Bus & $|\mathrm{V}|$ & $\delta$ & Generation & Load & Note \\
\hline 1 & 1.04 & 0 & - & 0 & Slack \\
2 & 1.02 & - & $1.50+\mathrm{j}-$ & 0 & PV \\
3 & 1.01 & - & $1.00+\mathrm{j}-$ & 0 & PV \\
4 & - & - & 0 & 0 & PQ \\
5 & - & - & 0 & $1.25+\mathrm{j} 0.50$ & PQ \\
6 & - & - & 0 & $0.90+\mathrm{j} 0.30$ & PQ \\
7 & - & - & 0 & 0 & PQ \\
8 & - & - & 0 & $1.00+\mathrm{j} 0.35$ & PQ \\
9 & - & - & 0 & 0 & PQ \\
\hline
\end{tabular}

Table 5. Wind power plant data

\begin{tabular}{cl}
\hline Component & \multicolumn{1}{c}{ Parameter } \\
\hline \multirow{2}{*}{ SCIG } & Stator: $\mathrm{R}_{\mathrm{S}}=0.002 ; \mathrm{X}_{\mathrm{S}}=0.024$ \\
& Rotor: $\mathrm{R}_{\mathrm{R}}=0.010 ; \mathrm{X}_{\mathrm{R}}=0.040$ \\
& Magnetic core: $\mathrm{X}_{\mathrm{m}}=8$ \\
Step-up transformer & Impedance: $\mathrm{Z}_{\mathrm{T}}=0.002+\mathrm{j} 0.080$ \\
\hline
\end{tabular}

\subsection{Results and discussion}

The load flow studies in the present work are carried out for various values of $\mathrm{P}_{\mathrm{m}}$ (i.e. from 0.1 to $1.0 \mathrm{pu}$ ). The calculation results in terms of voltage magnitude and electric power output of the WPP are shown in Table 6. As a comparison, results of the calculation when the previous T-circuit model [23] is used are also shown in the table. It can be seen that both results are in exact agreement which indicates that the model proposed is also valid. 
Table 6. WPP voltage magnitude and power output

\begin{tabular}{ccccc}
\hline \multirow{2}{*}{$\mathrm{P}_{\mathrm{m}}$} & \multicolumn{2}{c}{ Voltage magnitude (in pu) } & \multicolumn{2}{c}{ Power output (in pu) } \\
\cline { 2 - 5 } & Proposed model & Previous model [23] & Proposed model & Previous model [23] \\
\hline 0.1 & 0.9645 & 0.9645 & $0.0998-\mathrm{j} 0.1167$ & $0.0998-\mathrm{j} 0.1167$ \\
0.2 & 0.9641 & 0.9641 & $0.1995-\mathrm{j} 0.1187$ & $0.1995-\mathrm{j} 0.1187$ \\
0.3 & 0.9628 & 0.9628 & $0.2988-\mathrm{j} 0.1219$ & $0.2988-\mathrm{j} 0.1219$ \\
0.4 & 0.9605 & 0.9605 & $0.3979-\mathrm{j} 0.1262$ & $0.3979-\mathrm{j} 0.1262$ \\
0.5 & 0.9572 & 0.9572 & $0.4967-\mathrm{j} 0.1318$ & $0.4967-\mathrm{j} 0.1318$ \\
0.6 & 0.9527 & 0.9527 & $0.5952-\mathrm{j} 0.1386$ & $0.5952-\mathrm{j} 0.1386$ \\
0.7 & 0.9470 & 0.9470 & $0.6935-\mathrm{j} 0.1467$ & $0.6935-\mathrm{j} 0.1467$ \\
0.8 & 0.9400 & 0.9400 & $0.7914-\mathrm{j} 0.1563$ & $0.7914-\mathrm{j} 0.1563$ \\
0.9 & 0.9314 & 0.9314 & $0.8889-\mathrm{j} 0.1674$ & $0.8889-\mathrm{j} 0.1674$ \\
1.0 & 0.9211 & 0.9211 & $0.9860-\mathrm{j} 0.1804$ & $0.9860-\mathrm{j} 0.1804$ \\
\hline
\end{tabular}

To support the WPP reactive-power demand and improve system voltage profile, the WPP can be equipped with a shunt capacitor. Table 7 shows the calculation results when capacitor of 0.15 pu in capacity is installed. Slip (s) of the WPP induction generator is also calculated and shown in Table 8. Slip is determined based on the induction generator rotor voltage $\left(V_{R}\right)$, and computed using the formula given in the appendix. To have a better observation, the results in Tables 6-8 are also presented in the forms of graphs as shown in Figures 5-8.

Figure 5 shows, as predicted, that the shunt capacitor is able to support the WPP reactive-power demand and improves system voltage profile. Figure 6 shows a graph where WPP active-power output $\left(\mathrm{P}_{\mathrm{g}}\right)$ is plotted against turbine mechanical power input $\left(\mathrm{P}_{\mathrm{m}}\right)$. It can be seen that the relationship is linear (i.e. $\mathrm{P}_{\mathrm{g}}$ is always proportional to $\mathrm{P}_{\mathrm{m}}$ ). However, the value of $\mathrm{P}_{\mathrm{g}}$ is a little bit smaller than $\mathrm{P}_{\mathrm{m}}$ as there are some losses in the WPP induction generator.

Plot of WPP reactive-power demand $\left(-\mathrm{Q}_{\mathrm{g}}\right)$ against turbine mechanical power input $\left(\mathrm{P}_{\mathrm{m}}\right)$ is shown in Figure 7. Unlike the graph in Figure 6, the relationship between $-Q_{g}$ and $P_{m}$ is not linear (i.e. it is exponential). This relationship indicates that WPP requires much higher amount of reactive-power with the increase of turbine mechanical power (i.e. WPP active-power output).

Table 7. WPP voltage magnitude and power output when capacitor installed (in pu)

\begin{tabular}{ccc}
\hline $\mathrm{P}_{\mathrm{m}}$ & Voltage magnitude & Power output \\
\hline 0.1 & 0.9970 & $0.0998-\mathrm{j} 0.1246$ \\
0.2 & 0.9968 & $0.1995-\mathrm{j} 0.1265$ \\
0.3 & 0.9957 & $0.2989-\mathrm{j} 0.1295$ \\
0.4 & 0.9937 & $0.3980-\mathrm{j} 0.1336$ \\
0.5 & 0.9908 & $0.4969-\mathrm{j} 0.1388$ \\
0.6 & 0.9869 & $0.5956-\mathrm{j} 0.1451$ \\
0.7 & 0.9820 & $0.6939-\mathrm{j} 0.1527$ \\
0.8 & 0.9759 & $0.7920-\mathrm{j} 0.1616$ \\
0.9 & 0.9686 & $0.8897-\mathrm{j} 0.1718$ \\
1.0 & 0.9599 & $0.9871-\mathrm{j} 0.1837$ \\
\hline
\end{tabular}

Table 8. Slip of WPP induction generator

\begin{tabular}{ccc}
\hline \multirow{2}{*}{$\mathrm{P}_{\mathrm{m}}$} & \multicolumn{2}{c}{ Slip (\%) } \\
\cline { 2 - 3 } & Without Capacitor & With Capacitor \\
\hline 0.1 & -0.1080 & -0.1011 \\
0.3 & -0.2158 & -0.2020 \\
0.4 & -0.3242 & -0.3032 \\
0.5 & -0.4338 & -0.4055 \\
0.6 & -0.5455 & -0.5093 \\
0.7 & -0.6601 & -0.6153 \\
0.8 & -0.7787 & -0.7245 \\
0.9 & -0.9025 & -0.8376 \\
1.0 & -1.0333 & -0.9558 \\
\hline
\end{tabular}


Figure 8 shows the graphs of negative slip (-s) against turbine mechanical power input $\left(\mathrm{P}_{\mathrm{m}}\right)$. It can be seen that for WPP without shunt capacitor, the values of slip vary in the range of $-0.1080 \%$ and $-1.1732 \%$. Whereas, for WPP with shunt capacitor, the range of variation is slightly smaller $(-0.1011 \%$ and $-1.0807 \%)$. These results are expected since system with shunt capacitor has a better voltage profile and will lead to a higher (or less negative) value of slip.

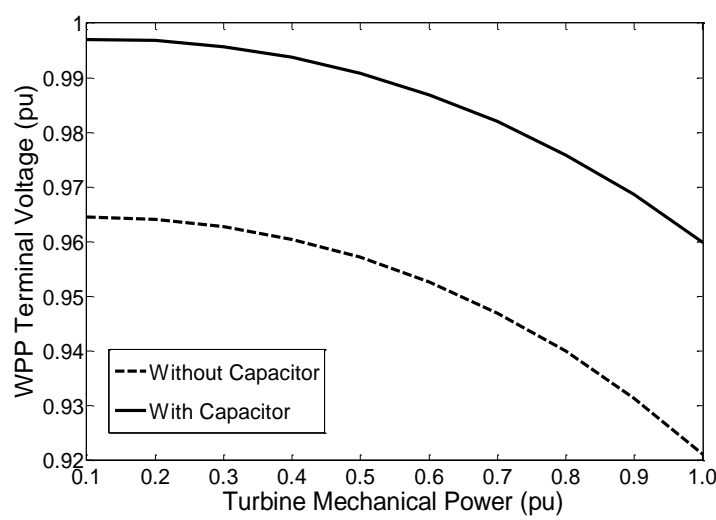

Figure 5. Variation of voltage magnitude

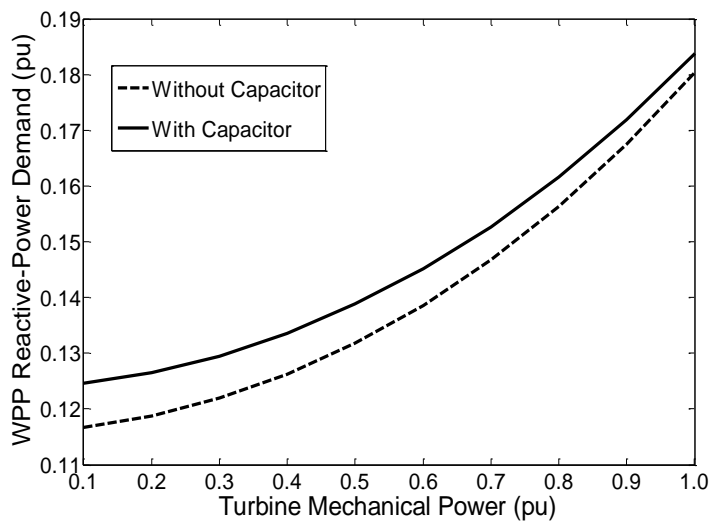

Figure 7. Variation of reactive-power

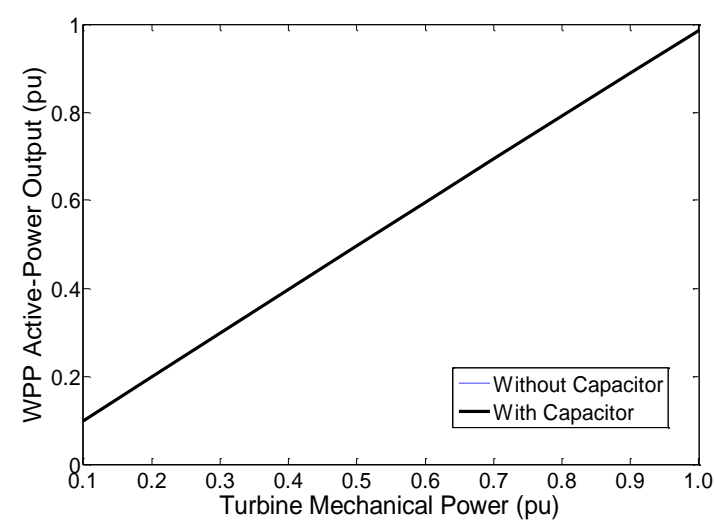

Figure 6. Variation of active-power

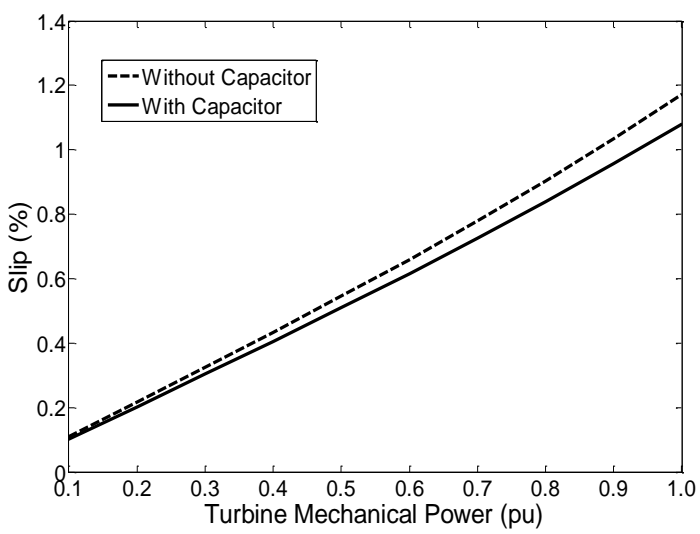

Figure 8. Variation of slip

\section{CONCLUSION}

A new steady state model of WPP has been presented in this paper. Similar to the previous T-circuit based models, it is also developed based on equivalent T-circuit of the WPP induction generator. However, unlike in the previous models, the mathematical formulation of the new model is shorter and less complicated. Moreover, the derivation process of the new model is much simpler. Only minimal mathematical operations are required in the process. Also, the rotor voltage value of the WPP induction generator is readily available as an output of the proposed model. This rotor voltage value can be used as a basis to calculate the induction generator slip. The validity of the proposed method has been tested on a representative 9-bus electrical power system installed with WPP. Comparative studies between the proposed method (new model) and other method (previous model) have also been carried out. Results of the studies confirm the validity of the new model.

\section{ACKNOWLEDGEMENTS}

The authors would like to express special appreciation to the Directorate General of Research and Development, Ministry of Research and Technology/National Agency for Research and Innovation (Kemenristek/BRIN Republik Indonesia) for funding the research reported in this paper. 


\section{APPENDIX}

A.1. Derivation of (9)

Applying Kirchhoff voltage law to the first loop of circuit in Figure 3 gives:

$$
\mathrm{V}_{\mathrm{S}}-\mathrm{V}_{\mathrm{M}}+\mathrm{Z}_{\mathrm{S}} \mathrm{I}_{\mathrm{S}}=0
$$

Since:

$$
\mathrm{V}_{\mathrm{M}}=\mathrm{Z}_{\mathrm{M}} \mathrm{I}_{\mathrm{M}}=\mathrm{Z}_{\mathrm{M}}\left(\mathrm{I}_{\mathrm{R}}-\mathrm{I}_{\mathrm{S}}\right)
$$

Then, by substituting (A.2) into (A.1) and rearranging, (9) can be obtained.

$$
\mathrm{V}_{\mathrm{R}}-\mathrm{V}_{\mathrm{M}}-\mathrm{Z}_{\mathrm{R}} \mathrm{I}_{\mathrm{R}}=0
$$

\section{A.2. Alternative expression to (11)}

Applying Kirchhoff voltage law to the second loop of circuit in Figure 3 gives:

Substituting (A.2) into (A.3) will result in:

$$
\mathrm{V}_{\mathrm{R}}-\left(\mathrm{Z}_{\mathrm{R}}+\mathrm{Z}_{\mathrm{M}}\right) \mathrm{I}_{\mathrm{R}}+\mathrm{Z}_{\mathrm{M}} \mathrm{I}_{\mathrm{S}}=0
$$

On using (6) and (7) in (A.4) will give:

$$
\mathrm{V}_{\mathrm{R}}-\left(\mathrm{Z}_{\mathrm{R}}+\mathrm{Z}_{\mathrm{M}}\right) \frac{\mathrm{P}_{\mathrm{m}}}{\mathrm{V}_{\mathrm{R}}^{*}}+\mathrm{Z}_{\mathrm{M}} \frac{\mathrm{S}_{\mathrm{g}}^{*}}{\mathrm{~V}_{\mathrm{S}}^{*}}=0
$$

Equation (A.5) is the alternative formulation to (11).

\section{A.3. Determination of machine slip based on rotor voltage}

Substituting (7) into (3) and rearrangement gives:

$$
\mathrm{s}=\mathrm{R}_{\mathrm{R}} /\left(\mathrm{R}_{\mathrm{R}}-\mathrm{V}_{\mathrm{R}} \mathrm{V}_{\mathrm{R}}^{*} / \mathrm{P}_{\mathrm{m}}\right)
$$

Since:

$$
\mathrm{V}_{\mathrm{R}} \mathrm{V}_{\mathrm{R}}^{*}=\left|\mathrm{V}_{\mathrm{R}}\right|^{2}
$$

Then, (A.6) can be rewritten as:

$$
\mathrm{s}=\mathrm{R}_{\mathrm{R}} /\left(\mathrm{R}_{\mathrm{R}}-\left|\mathrm{V}_{\mathrm{R}}\right|^{2} / \mathrm{P}_{\mathrm{m}}\right)
$$

\section{REFERENCES}

[1] K.C. Divya and R.P.S. Nagendra, "Models for Wind Turbine Generating Systems and Their Applications in Load Flow Studies," Electric Power Systems Research, vol. 76, n. 9-10, pp. 844-856, 2006.

[2] A. Feijoo, "On PQ Models for Asynchronous Wind Turbines," in IEEE Transactions on Power Systems, vol. 24, no. 4, pp. 1890-1891, Nov 2009.

[3] M. Zhao, Z. Chen and F. Blaaberg, "Load Flow Analysis for Variable Speed Offshore Wind Farms" IET Renewable Power Generation, vol. 3, no. 2, pp. 120-132, 2009.

[4] U. Eminoglu, "A New Model for Wind Turbine Systems," Electric Power Components and Systems, vol. 37, no. 10, pp. 1180-1193, 2009.

[5] U. Eminoglu, B. Dursun and M.H. Hocaoglu, "Incorporation of New Wind Turbine Generating System Model into Distribution Systems Load Flow Analysis," Wind Energy, vol. 12, no. 4, pp. 375-390, 2009.

[6] J.M. Ramirez, "Embedding PV and WF Models into Steady State Studies by an Optimization Strategy," Smart Grid and Renewable Energy, vol. 2, pp. 245-254, 2011. 
[7] L.M. Castro, "A Unified Approach for the Solution of Power Flows in Electric Power Systems Including Wind Farms," Electric Power Systems Research, vol. 81, no. 10, pp. 1859-1865, 2011.

[8] D. Villanueva, J. L. Pazos and A. Feijoo, "Probabilistic Load Flow Including Wind Power Generation," in IEEE Transactions on Power Systems, vol. 26, no. 3, pp. 1659-1667, Aug 2011.

[9] A. Dadhania, "Modeling of Doubly Fed Induction Generators for Distribution System Power Flow Analysis," International Journal of Electrical Power and Energy Systems, vol. 53, pp. 576-583, 2013.

[10] A. Feijoo A, J.L. Pazos JL and D. Villanueva D, "Conventional Asynchronous Wind Turbine ModelsMathematical Expressions for the Load Flow Analysis," International Journal of Energy Engineering, vol. 3, no. 6, pp. 269-278, 2013.

[11] W. Freitas, J. C. M. Vieira, A. Morelato, L. C. P. da Silva, V. F. da Costa and F. A. B. Lemos, "Comparative analysis between synchronous and induction machines for distributed generation applications," in IEEE Transactions on Power Systems, vol. 21, no. 1, pp. 301-311, Feb 2006.

[12] H. Li and Z. Chen, "Overview of Different Wind Generator Systems and Their Comparisons," IET Renewable Power Generation, vol. 2, no. 2, pp. 123-138, 2008.

[13] M.H. Haque, "Evaluation of Power Flow Solutions with Fixed Speed Wind Turbine Generating Systems," Energy Conversion and Management, vol. 79, pp. 511-518, 2014

[14] J. Wang, C. Huang and A.F. Zobaa, "Multiple-Node Models of Asynchronous Wind Turbines in Wind Farms for Load Flow Analysis," Electric Power Components and Systems, vol. 44, no. 2, pp. 135-141, 2015.

[15] M.H. Haque, "Incorporation of Fixed Speed Wind Turbine Generators in Load Flow Analysis of Distribution Systems," International Journal of Renewable Energy Technology, vol. 6, no. 4, pp. 317-324, 2015.

[16] V. S. S. Kumar and D. Thukaram, "Accurate Steady-State Representation of a Doubly Fed Induction Machine," in IEEE Transactions on Power Electronics, vol. 30, no. 10, pp. 5370-5375, Oct 2015.

[17] A. Feijóo and D. Villanueva, "A PQ Model for Asynchronous Machines Based on Rotor Voltage Calculation," in IEEE Transactions on Energy Conversion, vol. 31, no. 2, pp. 813-814, June 2016.

[18] A. Feijóo and D. Villanueva, "Correction to "A PQ Model for Asynchronous Machines Based on Rotor Voltage Calculation" [Jun 16 813-814]," in IEEE Transactions on Energy Conversion, vol. 31, no. 2, pp. 818-818, June 2016.

[19] M.H. Baloch, et al., "A Review of the State of the Art Control Techniques for Wind Energy Conversion System," International Journal of Renewable Energy Research, vol. 6, no. 4, pp. 1-20, 2016.

[20] O. Ozturk, M.E. Balc and M.H. Hocaoglu, "A New Wind Turbine Generating System Model for Balanced and Unbalanced Distribution Systems Load Flow Analysis,” Applied Sciences, vol. 8, no. 4, pp. 502-518, 2018.

[21] V. S. S. Kumar and D. Thukaram, "Accurate Modelling of Doubly Fed Induction Based Wind Farms in Load Flow Analysis," Electric Power Systems Research, vol. 15, pp. 363-371, 2018.

[22] R. Gianto, et al., "Two-Port Network Model of Fixed-Speed Wind Turbine Generator for Distribution System Load Flow Analysis," TELKOMNIKA Telecommunication Computing Electronics and Control, vol. 17, no. 3, pp. 1569$1575,2019$.

[23] R. Gianto, "T-Circuit Model of Asynchronous Wind Turbine for Distribution System Load Flow Analysis," International Energy Journal, vol. 19, no. 2, pp. 77-88, 2019.

[24] R. Gianto and K.H. Khwee, "A New Method for Load Flow Solution of Electric Power Distribution System," International Review of Electrical Engineering, vol. 11, no. 5, pp. 535-541, 2016.

[25] P.M. Anderson and A.A. Fouad, "Power System Control and Stability," Wiley-IEEE Press, New Jersey, 2003.

\section{BIOGRAPHIES OF AUTHORS}

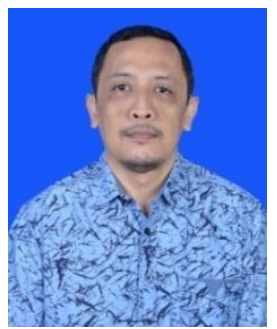

Rudy Gianto was born in Bandung, Indonesia. He received $\mathrm{BE}, \mathrm{ME}$ and $\mathrm{PhD}$ degrees from Tanjungpura University in 1991, Bandung Institute of Technology in 1995, and The University of Western Australia in 2009 respectively. Currently, he is an Associate Professor at Tanjungpura University, Indonesia. His research interests include power system analysis, simulation of power system dynamics, and distributed generation. He has published many research papers in international journals and conferences

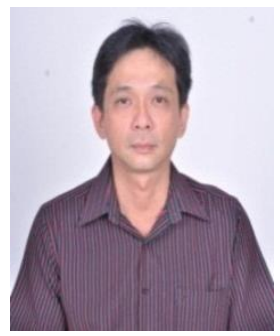

Kho Hie Khwee was born in Pontianak, Indonesia. He received BE, and ME degrees from Tanjungpura University in 1991, and Bandung Institute of Technology in 1995, respectively. Currently, he is an Associate Professor at Tanjungpura University, Indonesia. His research interests include analysis of power system, electrical machines, and renewable energy generation. He has published many research papers in international journals and conferences 